\title{
Phytochemical evaluation of Amorphophallus smithsonianus Sivad.: A rare endemic species from Western Ghats, Kerala, India
}

\author{
Raghavan Kavalan, A. K. Abdussalam * and K. M. Gothandam* \\ Department of Post Graduate Studies and Research in Botany, Sir Syed College, Karimbam P.O., Taliparamba-670142, Kannur, Kerala, India \\ *School of Biosciences and Technology, VIT University, Vellore-632014, Tamil Nadu, India
}

\section{Article Info}

\section{Article history}

Received 1 September 2020

Revised 20 October 2020

Accepted 23 October 2020

Published online 30 December 2020

\section{Keywords}

Amorphophallus smithsonianus Sivad.

Phytochemical

Antioxidant

Antibacterial

DPPH

Radical scavenging

\begin{abstract}
Amorphophallus smithsonianaus Sivad., a rare endemic species of the family Araceae from Western Ghats, Kerala, India has been evaluated for its phytochemicals, antioxidant potential and antibacterial properties. Morphological description of the species is also provided. For phytochemical screening, tuber was extracted in hexane, methanol and water. Preliminary phytochemical analysis revealed the presence of secondary metabolites such as reducing sugar, phenols, tannins, flavonoids, phytotannins, terpenoids, saponins, fats, oils, etc., in different extracts of the tuber. Out of three extracts, methanolic extracts of $A$. smithsonianus exhibited more phytochemicals. The tuber extracts exhibited antioxidant potential through DPPH radical scavenging assay and nitric oxide radical scavenging assay. The tuber extract of $A$. smithsonianus different extracts showed antibacterial property against the selected five pathogenic bacterial strains. The study suggests that the tuber of $A$. smithsonianus has good potential as a natural source of antioxidant.
\end{abstract}

\section{Introduction}

The genus Amorphophallus smithsonianus Sivad. is a member of the family Araceae, a natural group of monocotyledons with approximately 120 genera and 3800 species (Cusimano et al., 2011). The genus Amorphophallus with 200 species is the most diverse in the family with respect to its vegetative and reproductive characters such as habit, leaf morphology, inflorescence and most other characters that have been studied (Van der Ham et al., 2005). The species has been grouped together mainly on the basis of the distinctive inflorescences (Grayum, 1984). Amorphophallus is the second largest genera of the family Araceae in India (Jaleel et al., 2011). The genus Amorphophallus Blume ex Decne. is distributed in tropical Africa, Madagascar, India, Continental South East Asia, Malesia and North East Australia (Mayo et al., 1997).

The genus Amorphophallus exhibits lot of variation in vegetative as well as reproductive characters. The morphological similarity in the leaves of many species makes identification of the species with vegetative specimens difficult or impossible as the plant can be seen only either during vegetative stage or during flowering stage. Most of the time, the corms remain under the soil and it became impossible to identify and collect the plants. The plants

Corresponding author: Dr. A. K. Abdussalam Assistant Professor, Department of Post Graduate Studies and Research in Botany, Sir Syed College, Karimbam P.O., Taliparamba-670142, Kannur, Kerala, India

E-mail: salamkoduvally@gmail.com

Tel.: +91-9847654285

Copyright (c) 2020 Ukaaz Publications. All rights reserved.

Email: ukaaz@yahoo.com; Website: www.ukaazpublications.com flower usually before leaves come out, so collection of both inflorescence and leaves together is impossible in the genus. The flowering period is very short, once the vegetative period over, the plant loses their leaves leaving an underground corm which makes the detection and collection of the plant very difficult. Many species of Amorphophallus are endemic to particular area. In India, the genus is represented by 20 species (Jaleel et al., 2011), with the addition of a new species $A$. shyamsalilianum (Gadpayale, 2017) from Maharashtra. The number of species in the genus increased to 21 in the country. All the wild relatives of Amorphophallus except $A$. paeoniifolius are rare and are sparsely distributed (Jaleel et al., 2011). A. smithsonianus is a rare member of the aroid family, with limited population, strictly endemic to Agastyamalai hill ranges of Western Ghats, Thiruvanathapuram District, Kerala, India.

Species of the genus Amorphophallus are known to have a long history of use in tropical and subtropical Asia as a source of food, fodder and as traditional medicines for centuries and is a major ingredient in several herbal preparations (Hetterschied and Ittenback, 1996). A. paeoniifolius var. campanulatus, widely known as elephant foot yam is cultivated and used as vegetable. The tuberous corms of Amorphophallus are reported to be used for treatment of piles, cysts, and tumors (Ravikumar and Ved, 2004), cure for snake bite by tribals in some villages of Rajasthan, India (Jain et al., 2005; Kavitha et al., 2011), acute rheumatism, boils, abdominal tumors, enlargement of spleen and asthma (Yusuf et al., 1994). Tubers also serve as tonic, detoxifying agent, appetizer, gastro protective ability, antioxidative, antidiarrheal and anti-inflammatory activity (Singh and Wadhwa, 2014). 
It is reported that Kani tribes of Travancore hills consume the corms of $A$. smithsonianus for treatment of piles (Aravinthan, 2002). Phytochemical studies conducted in the genus are mostly confined to few widely available species only. Whereas, most of the wild relatives of the genus are unexplored regarding their phytochemical potential, perhaps due to their rare distribution and difficulty during its collection. Phytochemical and antibacterial property of $A$. commutatus var. wayanadenisis, an indigenous wild species endemic to Kerala was carried out by Krishna et al. (2013) and in A. commutatus (Kavitha et al., 2012), Damle and Kotian, (2015). Phytochemical evaluation of A. paeoniifolius was investigated for its pharmacognostic properties and various other potentials by (Dey and Ghosh, 2010; Firdouse and Alam, 2011; Dey et al., 2012; Madhurima et al., 2012; Madhavan and Raphel, 2012; Vora et al., 2015). Phytochemical and antimicrobial activity of $A$. sylvaticus (Revathi and Rani, 2014; Kavalan et al., 2018). Kavalan et al. (2018) studied the phytochemical and antibacterial properties of $A$. hohenackeri, a rare, endangered and threatened species of the genus. The phytochemical evaluation of $A$. smithsonianus, a rare endemic species found only in Agastyamalai hill ranges of Western Ghats, Kerala, India is studied for the first time to evaluate its phytochemical potentials.

1.1 Morphological and taxonomical description of the species

Amorphophallus smithsonianus Sivad. (Sivadasan, 1989), is a member of the family Araceae belongs to sect. conophallus (Jaleel et al., 2011). The species is not reported from any other place other than the type locality and is strictly endemic to floristically rich Agasthyamalai Hills, the southern end of Western Ghats, Thiruvanathapuram District of Kerala, India.

Tubers are compressed globose or irregularly sub-globose, usually 3-6 cm diam. The size of tuber increases during reproductive stage. Petiole smooth, cylindric ranging $24-60 \mathrm{~cm}$ long, smooth green with white specks and mottles, extreme base whitish and apical portion green, lamina ranges from $28-40 \mathrm{~cm}$ diam., leaflets obovate-oblong, acuminate. The leaflet margin erose, a unique character of the species (Figure 1: h)

Peduncle smooth, $8-12 \mathrm{~cm}$ long and gradually tapering to the tip, colour same as that of the petiole surrounded by 4-6 cataphylls. Spathe funnel-shaped, broadly obovate when spread with round or obtuse base, apex entire or notched, basally convolute with broadened mouth, pale green with minute purplish specks outside, dark purplish with minute truncate projections at the base within for about one third of the length, pale yellowish green or creamy and smooth above. Spadix sessile 4-5 times longer than the spathe, basal female approximately $1 \mathrm{~cm}$ long, neuteriflorous zone 0.5 $0.6 \mathrm{~cm}$ long, followed by a staminate portion and a terminal sterile appendix (Figure 1). Female flowers densely arranged, each flower with ovary cream-coloured; style very short; stigma sub equaling the ovary in diameter with stout echinations, pale green becoming cream in colour after anthesis. Neuter flowers in 2-5 rows, each obovoid or ellipsoid, dark-purlish, becoming shrunken and thin at maturity. Male flowers loosely arranged, cream-coloured, green with pale purplish tinge at the top. Spadix-appendix approximately $10-24 \mathrm{~cm}$ long, $0.8 \mathrm{~cm}$ diam. at the base and tapering to the tip, bent or hanging from the middle, dark purplish, tip sometimes purplish green, with irregular longitudinal shallow furrows, split into two longitudinal halves at maturity and bend downwards.

Phenology: Flowering usually occurs during November to December. Fruiting specimens could not observe and not reported earlier.

Distribution: The species is so far reported only from its type locality, i.e., Agasthyamalai hills of Western Ghats, Kerala, India
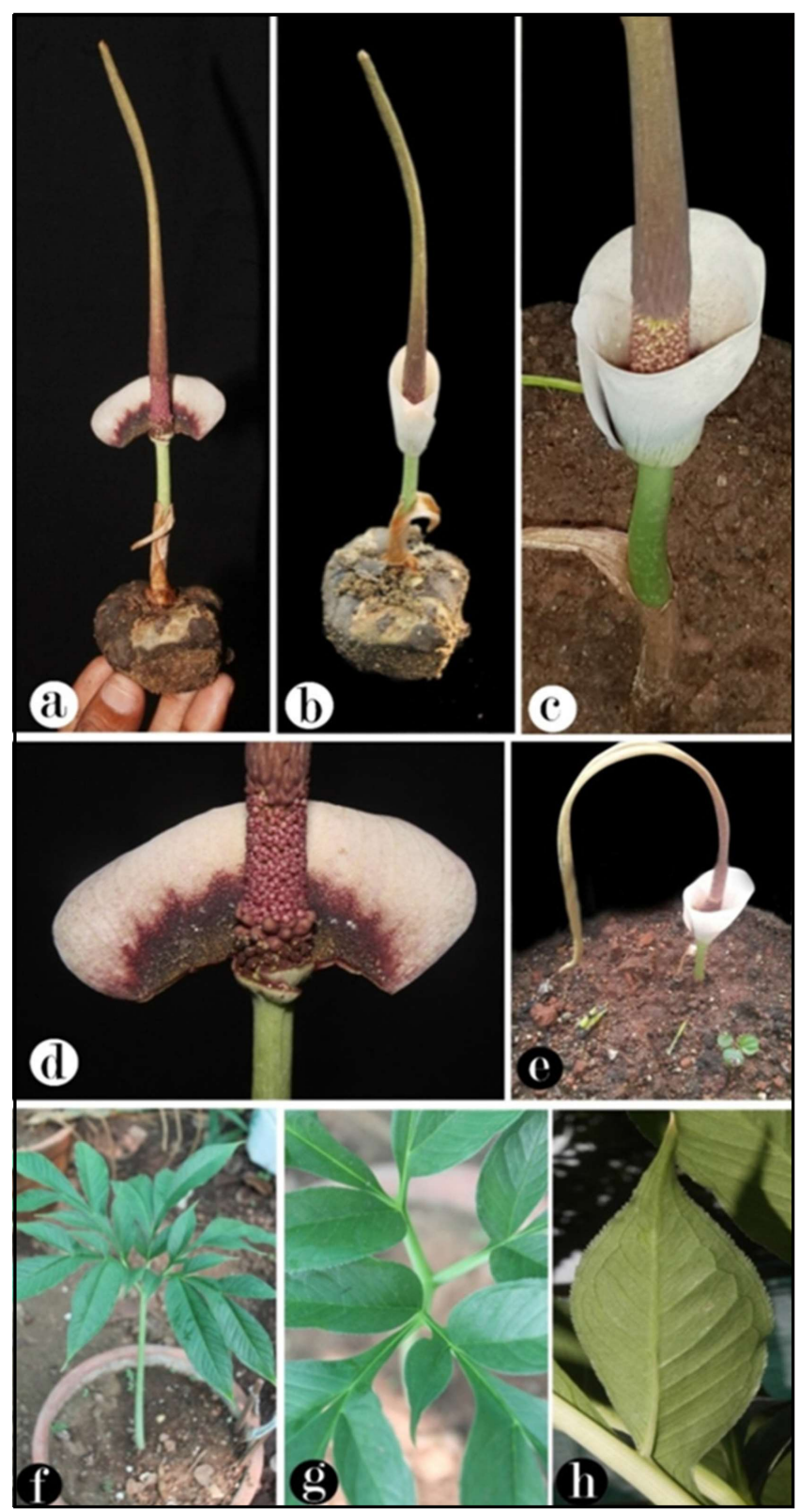

Figure 1: a - h: Amorphophallus smithsonianus. (a). Inflorescence along with tuber showing spadix cut open; (b). Inflorescence; (c). Inflorescence showing funnel shaped spathe. (d). A portion of spadix cut open showing male and female flowers; (e). Inflorescence at maturity showing pendant spadix appendix; (f). Petiole showing lamina; $(g, h)$. lamina showing erose leaflet margin. 


\section{Materials and Methods}

The tuber of the plant A. smithsonianus were collected from its natural locality, Agastyamalai hills, Thiruvanathapuram Dist. Kerala. The plant species were identified and authenticated by late Dr. V. Abdul Jaleel, Department of Post Graduate Studies and Research in Botany, Sir Syed College, Taliparamba, Kannur, Kerala, India and herbarium was deposited in the Sir Syed College and also maintained at the Aroid Home, Sir Syed College, Taliparamba, Kerala.

\subsection{Preparation of extracts}

For the phytochemical evaluation of the species, the tubers were properly washed, followed by surface sterilization using $1 \%$ of sodium hypochlorite (Maina et al., 2010). The tubers were chopped into pieces; sun dried, and powered using an electric blender. Extraction was done by Soxhlet apparatus (Gennaro et al., 2008) using solvents, viz: hexane, methanol, and water in the increasing order of their polarity and extract were stored in refrigerator (Ayvaz et al., 2008).

\subsection{Bacterial strains}

Five species of human pathogenic bacteria obtained from the National Collection of Industrial Microorganisms (NCIM), Pune, India, and Microbial Type Culture Collection (MTCC), Chandigarh, India available with School of Biosciences and Technology, VIT University were used for the present study. The gram-negative bacteria species used for evaluating the antibacterial activity of the species were Escherichia coli (NCIM 2810), Salmonella typhi (MTCC 733) and Proteus mirabilis (NCIM 2388). The gram-positive strains used are Listeria monocytogenes (NCIM 2106) and Bacillus cereus (NCIM 2458), these strains were preserved at $4^{\circ} \mathrm{C}$ in the nutrient broth as stock cultures and were sub-cultured for $24 \mathrm{~h}$ at $37^{\circ} \mathrm{C}$ prior to use. Kanamycin is used as standard. The obtained solvent extracts were concentrated using vacuum distillation process.

\subsection{Phytochemical analysis}

Phytochemical tests were carried out with hexane, methanol and aqueous extract of plant materials, using standard procedures (Trease and Evans, 1978; Edeoga et al., 2005). The analysis was done to test the presence of phytochemicals such as carbohydrates (Molisch's test), reducing sugars (Fehling's test), tannins (Ferric Chloride test), flavonoids (Shinoda test), steroids (Liebermann's Burchard's test), alkaloids (Wagner's Test), anthraquinones (Borntrager's test), glycosides ( Killer-Kilian test), phytotannins, terpenoids, saponins (Frothing test) and phenols (Ferric Chloride test).

\subsection{Antibacterial assay}

The antibacterial assay was performed on both gram positive and gram-negative bacteria species by well diffusion method (Onkar and Dhingra, 1995). The petri plates were poured with approximately $25 \mathrm{ml}$ autoclaved nutrient agar media each. Using a micropipette, standardized inoculums $(0.1 \mathrm{ml})$ of $0.5 \mathrm{McF}$ arland turbidity standards, equivalent to $5 \times 10^{8} \mathrm{cfu} / \mathrm{ml}$ (Lopez-Brea et al., 2008) was aseptically spread on the surface of nutrient agar plate. After drying, four wells were punched on each plate, using a sterile cork borer (Bradshaw, 1992). $0.1 \mathrm{ml}$ of each extract (concentration of $100 \mathrm{mg} / \mathrm{ml} \mathrm{each}$ ) was pipetted into respective wells (Ayfer and
Turgay, 2003). 10\% dimethyl sulfoxide. Kanamycin is used as positive drug control. The Petri plates were incubated overnight at $37^{\circ} \mathrm{C}$ and the antibacterial activity was measured after $18 \mathrm{~h}$ of incubation. The diameter of ZOI was also measured.

\subsection{DPPH assay}

The DPPH assay was performed to determine the free radical scavenging potential of extract. $1 \mathrm{ml}$ of $0.2 \mathrm{mM} \mathrm{DPPH}$ in methanol was mixed with $4 \mathrm{ml}$ of different concentration of extracts and standards. The solution is mixed vigorously and incubated in darkness for $30 \mathrm{~min}$. The free radical (1,1-diphenyl-2picryhydrazyl) which is absorbing UV-light at $517 \mathrm{~nm}$ will be reduced in the presence of antioxidant compound contained in the extract. This reaction will form a yellow molecule which will not absorb at the working wavelength. The more potential the extract is, the higher free radical scavenging, i.e., the lower absorbance at $517 \mathrm{~nm}$ is measured. The percentage of scavenging was calculated as follows: \% Scavenging $=(1-$ A sample $/$ A control $)$ $\mathrm{x} 100$, where A sample is absorbance measured in the presence of extract and A control is the one measured in absorbance of extract.

\subsection{Nitric oxide radical scavenging assay}

Nitric oxide scavenging activity of the extracts was determined. $1 \mathrm{ml}$ of $10 \mathrm{mM}$ sodium nitroprusside was mixed with $1 \mathrm{ml}$ of different concentration of extracts and standards and the mixture was incubated at $37^{\circ} \mathrm{C}$ for $150 \mathrm{~min}$. After incubation, $1 \mathrm{ml}$ of the mixture was taken out to which $1 \mathrm{ml}$ of Griess' reagent ( $1 \%$ sulphanilamide and $0.1 \%$ naphthyl ethylene diamine dihydrochloride in 2\% o-phosphoric acid) was added and the absorbance was measured at $546 \mathrm{~nm}$. The procedure is based on the principle that, sodium nitroprusside in aqueous solution at physiological $\mathrm{pH}$ spontaneously generates nitric oxide which interacts with oxygen to produce nitrite ions. These nitrite ions can react with Griess' reagent and to form a chromophore absorbing at $546 \mathrm{~nm}$. Scavengers of nitric oxide compete with oxygen, leading to reduce the production of nitrite ions. The absorbance of the chromophore which was formed will be measured at $546 \mathrm{~nm}$ and will decrease in presence of extracts. The percentage of scavenging was calculated as follows: \% Scavenging $=(1-$ A sample/A control $)$ $\mathrm{x} 100$, where A sample is the absorbance in the presence of extract and A control is the one measured I absence of extract.

\section{Results}

Phytochemical constituents play a vital role in the pharmaceutical properties of the plant. In current study, extracts were used for different type of analysis, which are statistically evaluated and discussed with relevant literature.

\subsection{Qualitative phytochemical screening}

The preliminary screening of $A$. smithsonianus tuber in hexane, methanol and aqueous extracts showed the presence of different kinds of phytochemicals such as tannins, alkaloids, anthraquinones, glycosides, phytotannins, terpenoids, saponins, phenolics, reducing sugars and carbohydrates (Table 1). Preliminary results exhibited the presence of secondary metabolites such as reducing sugars, tannins, flavonoids, phytotannins, terpenoids, saponins, fats and oils, etc., in methanolic extract of the tuber. Anthraquinones and alkaloids were not detected in any extracts. Phenolics were found in methanolic 
and hexane extract. Aqueous extracts were expressed carbohydrates, reducing sugars, flavonoids, glycosides besides saponins. Out of three extracts, methanolic extracts of $A$. smithsonianus expressed more phytochemicals in the preliminary screening.

Table 1: Qualitative phytochemical analysis of A. smithsonianus extracts, viz., water, hexane and methanol

\begin{tabular}{|l|c|c|c|}
\hline Phytochemicals & Water & Hexane & Methanol \\
\hline Carbohydrate & + & + & - \\
Reducing sugar & + & + & + \\
Tannins & - & - & + \\
Flavonoids & + & + & + \\
Alkaloids & - & - & - \\
Anthraquinones & - & - & - \\
Glycosides & + & + & - \\
Phyto tannins & - & - & + \\
Terpenoids & - & - & + \\
Saponins & + & - & + \\
Fats and oils & - & + & + \\
Phenolics & - & + & + \\
\hline
\end{tabular}

+ indicates presence, - indicates absence.

\subsection{DPPH radical scavenging assay}

The antioxidant activities of methanolic, hexane and water extract of $A$. smithsonianus using the DPPH radical scavenging activity was shown in Figure 2. About $50-300 \mu \mathrm{g} / \mathrm{ml}$ of methanolic extracts produced moderate to high DPPH radical scavenging in all concentration in the increasing order $(26.12 \%$ to $81.92 \%)$. Highest scavenging activity is found in methanolic extract of A. smithsonianus, i.e., $81.92 \%$ at $300 \mu \mathrm{g} / \mathrm{ml}$ which is nearer to the standard ascorbic acid. The radical scavenging activity of hexane extract and aqueous extract was found relatively lower compared to methanolic extract and below the performance of standard.

Table 2: DPPH scavenging assay of A. smithsonianus in different tuber extracts, viz., hexane, methanol and water

\begin{tabular}{|l|l|l|l|}
\hline $\begin{array}{l}\text { A. smithsonianus } \\
\text { extract }(\mu \mathrm{g} / \mathrm{ml})\end{array}$ & Hexane & Methanol & Water \\
\hline 50 & $26.12 \pm 1.72$ & $60.89 \pm 2.49$ & $34.08 \pm 2.68$ \\
100 & $32.03 \pm 2.63$ & $72.12 \pm 2.13$ & $33.13 \pm 2.83$ \\
150 & $33.17 \pm 1.92$ & $75.41 \pm 3.91$ & $31.07 \pm 2.93$ \\
200 & $35.05 \pm 2.87$ & $75.62 \pm 2.63$ & $28.22 \pm 4.93$ \\
250 & $37.78 \pm 2.13$ & $80.18 \pm 4.69$ & $28.89 \pm 2.13$ \\
300 & $39.99 \pm 2.14$ & $81.92 \pm 3.17$ & $30.11 \pm 2.47$ \\
\hline
\end{tabular}

\pm Standard error

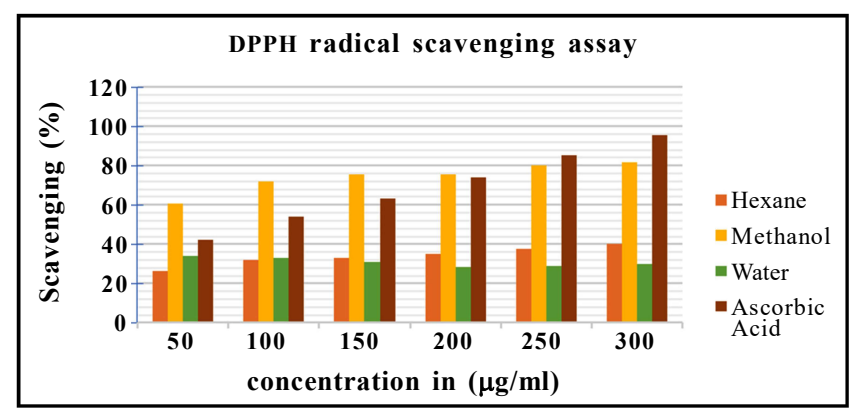

Figure 2: DPPH scavenging assay of A. smithsoniams in different tuber extracts, viz., hexane, methanol and water.

\subsection{Nitric oxide radical scavenging assay}

The antioxidant property of tuber extract of $A$. smithsonianus in hexane, methanol and aqueous extracts was studied by employing nitric oxide radical scavenging assay. 50-300 $\mu \mathrm{g} / \mathrm{ml}$ of methanol extracts produced moderate to high radical scavenging property ranging from $67.29 \%$ to $84.65 \%$. The highest antioxidant activity was found in methanolic extract which is $84.65 \%$ and is almost nearer to ascorbic acid standard. Whereas hexane and aqueous extract showed less inhibitory activity as shown in the Figure 3, which is far less than methanolic extract. However, the radical scavenging activity was found higher in hexane extract at all concentrations compared to aqueous extract. Methanolic extract of A. smithsonianus tuber shows more scavenging activity and has as a good antioxidant potential.

Table 3: Nitric oxide radical scavenging assay of $A$. smithsonianus extract, viz., hexane, methanol and water

\begin{tabular}{|l|l|l|l|}
\hline $\begin{array}{l}\text { A. smithsonianus } \\
\text { extract }(\mu \mathrm{g} / \mathrm{ml})\end{array}$ & Hexane & Methanol & Water \\
\hline 50 & $42.31 \pm 2.44$ & $67.29 \pm 2.41$ & $22.32 \pm 2.41$ \\
100 & $44.54 \pm 1.42$ & $71.21 \pm 2.46$ & $32.43 \pm 2.13$ \\
150 & $45.13 \pm 2.41$ & $72.34 \pm 1.49$ & $36.45 \pm 2.41$ \\
200 & $45.09 \pm 1.43$ & $73.56 \pm 1.48$ & $38.63 \pm 2.41$ \\
250 & $45.86 \pm 2.41$ & $78.43 \pm 2.46$ & $40.41 \pm 2.03$ \\
300 & $47.98 \pm 2.41$ & $84.65 \pm 2.41$ & $43.07 \pm 1.91$ \\
\hline
\end{tabular}

\pm Standard error

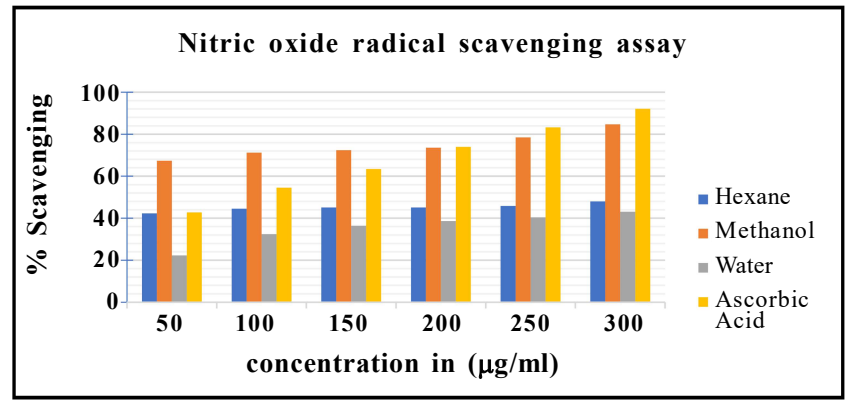

Figure 3: Nitric oxide radical scavenging assay of $A$. smithsonianus different extracts.

\subsection{Antibacterial activity}

Antibacterial property of $A$. smithsonianus tuber extracts was studied using agar well diffusion method against five pathogenic bacterial strains which include both gram-positive and negative. The zone of inhibition is shown in Table 4. Aqueous extract exhibited highest inhibitory effect against four bacterial strains with highest against $S$. typhi and E. coli $(14 \mathrm{~mm})$. Methanolic extract showed inhibition against $P$. mirabilis $(13 \mathrm{~mm}), E$. coli $(11 \mathrm{~mm})$ and L. monocytogenes and $S$. typhi $(09 \mathrm{~mm})$ which is less than standard kanamycin. Hexane extract expressed slight antibacterial property against two microbes only, i.e., Bacillus cereus $(11 \mathrm{~mm})$ and $S$. typhi $(08 \mathrm{~mm})$ which is also lower than standard. Out of three tuber extracts, only aqueous extract was found effective against $S$. typhi and found better than kanamycin standard. 
Table 4: Antimicrobial properties of $A$. smithsonanus tuber extract against different bacteria. Zone of inhibition (ZOI) expressed in $\mathrm{mm}$

\begin{tabular}{|c|c|c|c|c|}
\hline Bacterial strain & $\begin{array}{c}\text { Kanamycin } \\
\text { standard }\end{array}$ & Hexane & Methanol & Water \\
\hline E. coli & $18 \pm 0.23$ & - & $11 \pm 0.15$ & $14 \pm 0.19$ \\
\hline $\begin{array}{l}\text { Listeria } \\
\text { monocytogens }\end{array}$ & $14 \pm 0.17$ & -- & $09 \pm 0.34$ & -- \\
\hline Bacillus cereus & $18 \pm 0.37$ & $11 \pm 2.41$ & -- & $09 \pm 0.27$ \\
\hline Salmonella typhi & $12 \pm 0.31$ & $08 \pm 2.41$ & $09 \pm 0.34$ & $14 \pm 0.35$ \\
\hline Proteus mirabilis & $15 \pm 0.26$ & -- & $13 \pm 0.43$ & $10 \pm 0.27$ \\
\hline
\end{tabular}

$\pm \mathrm{SD}$, --Indicates no antibacterial activity.

\section{Discussion}

Plants and their products are extensively being used for traditional medicines for various ailments as it contains many phytoconstituents. It is reported that Kani tribes of Agastyhamalai uses A. smithsonianus traditionally for the treatment of piles (Aravinthan, 2002). Phytochemical studies have been carried out on few species of the genus in the country such as $A$. paeonifolius, $A$. commutatus, A. sylvaticus, A. bulbifer and A. hohenackeri, etc., whereas $A$. smithsonianus, a rare endemic species of the genus is unexplored for its phytoconstituents. The preliminary phytochemical screening of the plant revealed the presence of many secondary metabolites like tannins, phenols and flavonoids, etc., in different extracts that form the foundation of their pharmacological activity (Table 1). The presence of various phytochemicals in A. smithsonianus tuber is in conformity with the similar results reported earlier from other members of the genus such as A. paeoniifolius (Dey and Ghosh, 2010; Dey et al., 2012; Madhurima et al., 2012; Madhavan and Raphel, 2012; Vora et al., 2015). The studies conducted by Krishna et al. (2013) and Damle and Kotian, (2015) also observed similar phytochemicals in varieties of A.commutatus. Kavalan et al. (2018) also reported similar results in A.sylvaticus and $A$. hohenackeri. The presence of various phytochemicals in $A$. smithsonianus as in other members of the genus studied reveals the potential of this plant in traditional herbal medicine. Antioxidant capacity and radical scavenging ability evaluated in DPPH and nitric oxide radical scavenging assay shows that the tuber extract possess varying degree of radical scavenging potential at different concentrations in different extracts. Highest radical scavenging potential in DPPH was observed in methanolic extract (Table 2 and Figure 2). The assessment of antioxidant potential of the tuber extract in nitric oxide radical scavenging assay shows that methanolic tuber extract possesses good radical scavenging potential on par with ascorbic acid standard in different concentrations (Table 3 and Graph 3). Antimicrobial study also shows that $A$. smithsonianus is having antibacterial potential against pathogenic bacteria studied. The zone of inhibition was less than standard against all pathogenic strains except Salmonella typhi (Table 4). The phytochemical evaluation carried out on A. smithsonianus reveals that, this rare endemic species of the genus Amorphophallus can be considered as a natural source of antioxidant and as an antibacterial. As the plant is endemic to Agastyamalai hills and confined to limited area with very less population, attention of conservationists is required to protect and propagate this rare species of the aroid family for future.

\section{Conclusion}

Traditional use of $A$. smithsonianus is an indication that the plant is having medicinal properties. No studies have been carried out on A. smthsonianus either in India or elsewhere regarding the study of its phytochemical constituents, antioxidant potential and antibacterial activities, probably due to its rare distribution and difficulty in collection. The study carried out confirmed that the tuber extract of the plant contains various secondary metabolites and possess antioxidant ability. Methanol extract was found more effective to express the phytochemicals present in the plant and to show the free radical scavenging potential compared to hexane and water extract. The activity is found to be higher than that of standard ascorbic acid. The tuber extract also exhibited antibacterial efficacy against few pathogenic bacteria with aqueous extract perform better than standard against $S$. typhi. The study reveals that this rare member of the aroid family possesses good therapeutic potential which requires further studies for the elucidation of bioactive compounds.

\section{Acknowledgements}

We thank the Principal, Sir Syed College, Taliparamba, Kannur, Kerala and management of VIT University, Vellore, Tamil Nadu for extending the lab facilities of School of Biosciences and Technology for performing the experiments. First author expresses his gratitude to Commissioner, Navodaya Vidyalaya Samiti, Noida for permitting him to undertake the study, Dr. M. Sivadasan, former Professor, King Saud University, Saudi Arabia and Shri. A.N. Ramachandra, former Joint Commissioner, NVS for the motivation and encouragement.

\section{Conflict of interest}

The authors declare that there are no conflicts of interest in the course of conducting the research. Both the authors had final decision regarding the manuscript and decision to submit the findings for publication.

\section{References}

Ayvaz, A.; Osman, S.; Salih, K. and Ismet, O. (2008). Insecticidal activity of the essential oils from different plants against three stored product insects. J. Insect Sci., 10:1-13.

Aravinthan, K.M. (2002). In vitro studies on Amorphophallus smithsonianus Sivadasan: An endemic aroid. Ph.D. Thesis, Bharathiar University, Coimbatore, Tamil Nadu.

Ayfer, A.D. and Turgay, Z.E. (2003). Antimicrobial activities of various medicinal and commercial plant extracts. Turk. J. Biol., 27:157-162.

Bradshaw, L.J. (1992). Laboratory microbiology. 4th ed. Saunders College Publishing, Fort Worth, USA, pp:435.

Cusimano, N.; Mayo, S.J.; Boyce, P.C.; French, J.C.; Keating, R.C.; Sin, Y. Wong; Hetterschied, W.L.A. and Bogner, J. (2011). Relationship within the Araceae: Comparison of morphological patterns with molecular phylogenies. American Journal of Botany, 98(4):1-15.

Damle, S. and Kotian, A. (2015). Elemental, Phytochemical and Antibacterial analysis of Amorphophallus commutatus Lnn. International Journal of Recent Scientific Research, 6(5):4308-4311.

Dey, Y.N. and Ghosh, A.K. (2010). Pharmacognostic and phytochemical analysis of the tuber Amorphophallus paeonifolius. Indian Journal of Pharma. Research and Development, IJPRD., 2(9):44-49. 
Dey, Y.N.; Sarada, Ota; Shrikant, N.; Mahvish, Jamal and Wanjari, M. (2012). A phytochemical review of on an important medicinal plant Amorphophallus paeoniifolius. Ayu., 33(1):27-32.

Edeoga, H.O.; Okwu, D.E. and Mbaebie, B.O. (2005). Phytochemical constituents of some Nigerian medicinal plants. Afr. J. Biotechnol., 4(7):685-688.

Firdouse, S. and Alam, P. (2011). Phytochemical investigation of extract of Amorphophallus campanulatus tubers. Int. J. Phytomed., 3(1):32-35.

Gadpayale, J.V.; Somkuwar, S.R. and Chathurvedi, A.A. (2017). Amorphophallus shyamsalilianum a new species (Araceae) from Bhandra District, Maharashtra State, India. Phytotaxa., 312(1):118-122.

Gennaro, L.; Sukhdev, S.H.; Suman Preet, S.; Khanuja and Dev Dutt, R. (2008) Extraction technologies for medicinal and aromatic plants. United Nations Industrial Development Organization and the International Centre for Science and High Technology, Trieste, Italy, pp:23.

Grayum, M.H. (1984). Palynology and phylogeny of the araceae. Ph.D. Thesis, University of Massachusetts, USA.

Hetterscheid, W.L.A. and Ittenbach, S. (1996). Everything you always wanted to know about Amorphophallus, but were afraid to stick your nose into. Aroideana., 19:7-131.

Jain, A.; Katewa, S.S.; Galav, P.K. and Sharma, P. (2005). Medicinal plan diversity of Sitamata wild life sanctuary, Rajasthan, India. J. Ethnopharmacol., 102:143-157.

Jaleel, V.A.; Sivadasan, M.; Ahmed H. Alfarhan; Jacob Thomas and Alatar, A.A. (2011). Revision of Amorphophallus Blume ex Decne.sect. Raphiophallus (Schott) Engl. (Araceae) in India. Bangladesh Journal of Plant Taxon., 18(1):1-26

Kavalan, R.; Jaleel, V.A. and Gothandam, K.M. (2018). Morphological, Phytochemical and Antibacterial properties of Amorphophallus sylvaticus (Araceae). Int. J. Adv. Res., 6(10):886-894.

Kavalan, R.; Jaleel, V.A. and Gothandam, K.M. (2018). Phytochemical and Antibacterial Analysis of Amorphophallus hoheneackeri (Schott) Engl. Gehrm. Eco Chronicle, 13(2):69-74.

Kavitha, K.R.; Karthikeyan, S. and Krishna, K.S. (2011). Anti-bacterial activity of Amorphophallus commutatus, an endemic plant of Western Ghats, South India. J. Pharm. Res., 4(3):710-711.

Kavitha, K.R.; Krishna Kumar, S.; Vinodha, M.; Anu Sebastian, and Gomathi, R. (2012): In vitro free radical scavenging activity of Amorphophallus commutatus an endemic aroid of Western Ghats, South India, International Research Journal of Pharmacy, 3(2):133-137.

Krishna, A.R.; Asis Singh; Abdul Jaleel, V.; Sreena Raj; Karthikeyan, S. and Gothandam, K.M. (2013). Morphological, phytochemical and antibacterial properties of wild and indigenous plant (Amorphophallus commutatus). Journal of Medicinal Plant Research, 7(13):744-748.
Lopez-Brea, M.; Alarcon, T.; Domingo, D. and Diaz Reganon, J. (2008). Inhibitory effect of Gram negative and gram-positive microorganism against Helicobactor pylori clinical isolates. J. Antimicrob. Chemother., 61:139-142.

Madhavan, M. and Raphel, R. (2012). Pharmacognostic and preliminary phytochemical screening of the corm Amorphophallus paeoniifolius (Dennst) Nicols. var. paeoniifolius. Academic Sciences, 4(5):238-240.

Madhurima, P.; Kuppsat, I.J. and Mankani, K.L. (2012). A review on Amorphophallus paeoniifolius. International Journal of Advanced Scientific Research and Technology, 2:99-111.

Maina, S.M.; Emongor, Q.; Sharma, K.K.; Gichuki, S.T.; Gathaara. M.; de Villiers, S.M. (2010). Surface sterilant effect on the regeneration efficiency from cotyledon explants of groundnut (Arachis hypogea L.) varieties adapted to Eastern and Southern Africa. Afr. J. Biotechnol., 9(20):2866-2871.

Mayo, S.J.; Bogner, J. and Boyce, P.C. (1997). Amorphophallus: In: The genera of Araceae. Royal Botanic Gardens, Kew, pp:235-239.

Onkar, D. and Dhingra, J.B. (1995). Basic plant pathology methods. 2nd edition. Lewis Publishers, Boca Raton, pp:287-305.

Ravikumar, K. and Ved, D.K. (2004). Illustrated Field Guide-100 Red listed medicinal plants of conservation concern in South India, FRLHT, Bangalore, pp:1-467.

Revathi, E. and Rani, G. (2014). Antimicrobial potential activity of Amorphophallus sylvaticus extract against Oral microorganisms. IJIPBART, 1(1):38-46.

Shete, C.C.; Wadkar, S.S.; Gaikwad, N.B.; Patil, K.S. and Ghosh, J.S. (2015). Phenolic content and antioxidant capacity of Amorphophallus commutatus and Amorphophallus paeoniifolius. International Food Research Journal, 22(5):1939-1944.

Singh, A. and Wadhwa, N. (2014). A review on multiple potential of aroid: Amorphophallus paeoniifolius. Int. J. Pharm. Sci. Rev. Res., 24:55-60.

Sivadasan, M. (1989). Amorphophallus smithsonianus (Araceae), a new species from India, and a note on A. sect. Synantherias. Willdenowia, 18:435-440.

Trease, G.E. and Evans, W.C. (1978). A text book of pharmacognosy, 11th edition. Bailliere Tindall London, pp:530.

Van der Ham, R.W.J.M.; Grob,G.B.J.; Hetterscheid, W.L.A.; Star, W. and Van Heuven, B.J. (2005). Notes on the genus Amorphophallus (Araceeae)13. Evolution of pollen ornamentation and ultra-structure in Amorphophallus and Pseudodracontium. Grana, 44:252-265.

Vora, J.D.; Aswathi Sarman, M.S. and Nonita Madhrani (2015). Biochemical, organoleptic and antimicrobial assessment of elephant foot yam (Amorphophallus paeonifolius). Journal of Environmental Science, Toxicology and Food Technology, 9(5)1:7-10.

Yusuf, M.; Chowdhury, J.U.; Yahab, M.A. and Begum, J. (1994). Medicinal Plants of Bangladesh, Dhaka, BCSIR Laboratories.

Citation Raghavan Kavalan, Abdussalam A. K. and K. M. Gothandam (2020). Phytochemical evaluation of Amorphophallus smithsonianus Sivad.: A rare endemic species from Western Ghats, Kerala, India. Ann. Phytomed., 9(2):271-276. http://dx.doi.org/10.21276/ap.2020.9.2.26 